\title{
Health Physics Enrollments and Degrees Survey, 2010 Data
}

(June 2011 Update)

(One academic program provided additional data after the original publication distribution, and these revisions are included in this updated report.)

\section{SURVEY UNIVERSE}

The survey includes degrees granted between September 1, 2009 and August 31, 2010. Enrollment information refers to the fall term 2010. Twenty-four academic programs were included in the survey universe, and all 24 programs provided data. This is the same number of programs reporting as last year, but represents an addition of two new programs which offsets a loss of two programs compared to the 2009 report. The enrollment and degree data includes students majoring in health physics or in an option program equivalent to a major. Enrollment and degree data for health physics options within nuclear engineering programs are reported in both the health physics and nuclear engineering reports.

\section{DEGREE DATA}

Bachelor's Degrees. The number of B.S. degrees granted in 2010 was lower than in 2009 but remains higher than levels experienced in the first half of the decade. (See Table 1.) The current number of B.S. degrees is approximately $32 \%$ below the number of B.S. degrees reported for 1995 . Health physics programs accounted for over $85 \%$ of all reported B.S. degrees. (See Table 2.)

Graduate Degrees. The number of master's degrees granted in 2010 was $7 \%$ higher than the number reported in 2009 and is similar to the numbers reported for 2006 and 2007 . The number of doctoral degrees granted in 2010 rose significantly from 2009 and is the second highest reported since 2003. (See Table 1.) Health physics programs accounted for $80 \%$ of the master's degrees and $60 \%$ of the doctoral degrees. (See Table 2.)

Table 1. Health Physics Degrees, 2003 - 2010

\begin{tabular}{lcrc} 
& \multicolumn{3}{c}{ Degrees } \\
\cline { 2 - 4 } Year & B.S. & M.S. & Ph.D. \\
\hline 2010 & 62 & 89 & 15 \\
$2009^{*}$ & 77 & 83 & 9 \\
2008 & 73 & 108 & 8 \\
2007 & 79 & 91 & 28 \\
2006 & 71 & 90 & 12 \\
2005 & 78 & 77 & 14 \\
2004 & 54 & 64 & 14 \\
2003 & 56 & 73 & 25
\end{tabular}

*Data for one program was estimated for 2009.

Table 2. Health Physics Degrees by Curriculum, 2010

\begin{tabular}{lrrc} 
& \multicolumn{3}{c}{ Degrees } \\
\cline { 2 - 4 } \multicolumn{1}{c}{ Curriculum } & B.S. & M.S. & Ph.D. \\
\hline Health Physics Program & 53 & 71 & 9 \\
Medical Health Physics & 0 & 18 & 4 \\
Other Health Physics Option & 9 & 0 & 2
\end{tabular}




\section{ENROLLMENTS AND SHORT-TERM OUTLOOK FOR DEGREE TRENDS}

Undergraduate Students. In 2010, the reported enrollment of junior and senior undergraduate students was approximately 200 , a $13 \%$ decrease over 2009. The decrease in 2010 undergraduate enrollments offsets the increase in enrollments in 2009. Together, the enrollment data for these two years indicate that the number of B.S. degrees is likely to remain in the 60 to 75 range in 2011, and may decrease modestly in 2012.

Graduate Students. Graduate enrollment reported for 2010 was 375 students. This is a very slight increase from graduate enrollment in 2009. The enrollment trends indicate that the number of M.S. degrees is likely to remain relatively constant for the next two to three years. The number of doctorate degrees is likely to remain near 2010 levels over the next few years as graduate enrollments have been higher for the past seven years, and many of these students may still be in the pipeline.

\section{EMPLOYMENT OR OTHER POST-GRADUATION STATUS}

Continued study, nuclear utility employment, and active duty in the U.S. military were the largest postdegree activities reported for B.S.-level graduates; for M.S.-level graduates, other nuclear-related employment, continued study, and Federal government employment were the largest post-degree activities reported for M.S. level graduates. (See Table 3.) Academic employment was the largest planned activity reported for Ph.D. level graduates.

The 2010 post-graduation distribution of employment or other post-graduation plans differs somewhat for B.S. and Ph.D. graduates when compared to plans reported for 2008. No post-graduation plans were reported this time for 2010 B.S. degree graduates for either academic employment or other nuclearrelated employment, and in contrast to 2008 , one-third of postgraduate plans for Ph.D. recipients were reported as either unknown/not reported or still seeking employment. Two Ph.D. recipients had plans to enter the U.S. military.

Table 3. Employment or Other Post-Graduation Plans, 2010

Continued Study

Academic Employment

Federal Government Employment

DOE Contractor Employment

State and Local Government Employment

Nuclear Utility Employment

Other Nuclear-Related Employment

Other Business Employment

Foreign (non-U.S.) Employment

U.S. Military, Active Duty

Other Employment

Still Seeking Employment

Unknown/Not reported

Totals

\begin{tabular}{rcc}
\multicolumn{3}{c}{ Degrees } \\
\hline B.S. & M.S. & Ph.D. \\
\hline 19 & 17 & 2 \\
0 & 4 & 3 \\
2 & 9 & 0 \\
2 & 4 & 0 \\
0 & 2 & 0 \\
9 & 5 & 0 \\
0 & 17 & 1 \\
1 & 6 & 1 \\
0 & 0 & 0 \\
5 & 6 & 2 \\
2 & 0 & 1 \\
4 & 3 & 1 \\
18 & 16 & 4 \\
\hline
\end{tabular}

62

89

15 
Table 4. Health Physics Degrees, 2010, by Academic Institution

(alphabetical by state and then university)

Degrees

\begin{tabular}{|c|c|c|c|c|}
\hline \multirow[b]{2}{*}{ State } & \multirow[b]{2}{*}{ Name of Institution } & \multicolumn{3}{|c|}{ Sept. 1, 2009 - Aug. 31, 2010} \\
\hline & & B.S. & M.S. & Ph.D. \\
\hline CA & San Diego State University & 0 & 2 & 0 \\
\hline $\mathrm{CO}$ & Colorado State University & 0 & 5 & 1 \\
\hline DC & Georgetown University & 0 & 3 & 0 \\
\hline ID & Idaho State University & 0 & 4 & 2 \\
\hline IL & Illinois Institute of Technology & 0 & 11 & 0 \\
\hline IN & Purdue University & 6 & 2 & 0 \\
\hline LA & Louisiana State University & 0 & 5 & 0 \\
\hline MA & University of Massachusetts, Lowell & 2 & 12 & 2 \\
\hline ME & University of Maine & 5 & 0 & 0 \\
\hline MO & University of Missouri - Columbia & 0 & 7 & 2 \\
\hline NC & Duke University & 0 & 2 & 2 \\
\hline $\mathrm{NJ}$ & Thomas Edison State College & 9 & 0 & 0 \\
\hline NM & University of New Mexico & 0 & 1 & 0 \\
\hline NV & University of Nevada, Las Vegas & 2 & 5 & 0 \\
\hline NY & Rensselaer Polytechnic Institute & 10 & 1 & 2 \\
\hline $\mathrm{OH}$ & University of Cincinnati & 0 & 0 & 0 \\
\hline OR & Oregon State University & 10 & 20 & 0 \\
\hline PA & Bloomsburg University of Pennsylvania & 2 & 0 & 0 \\
\hline SC & Clemson University & 0 & 0 & 2 \\
\hline SC & Francis Marion University & 3 & 0 & 0 \\
\hline $\mathrm{TN}$ & University of Tennessee & 7 & 2 & 2 \\
\hline $\mathrm{TN}$ & Vanderbilt University & 0 & 0 & 0 \\
\hline $\mathrm{TX}$ & Texas A\&M University & 6 & 7 & 0 \\
\hline $\mathrm{TX}$ & University of Texas & 0 & 0 & 0 \\
\hline Total & & 62 & 89 & 15 \\
\hline
\end{tabular}


Prepared by: Analysis and Evaluation Group, Science Education Programs, Oak Ridge Institute for Science and Education, June 2011.

This document was prepared for U.S. Nuclear Regulatory Commission by the Oak Ridge Institute for Science and Education (ORISE) through an interagency agreement with the U.S. Department of Energy (DOE). ORISE is managed by Oak Ridge Associated Universities under DOE contract number DE-AC05-06OR23100.

The Oak Ridge Institute for Science and Education (ORISE) is a U.S. Department of Energy institute focusing on scientific initiatives to research health risks from occupational hazards, assess environmental cleanup, respond to radiation medical emergencies, support national security and emergency preparedness, and educate the next generation of scientists. ORISE is managed by Oak Ridge Associated Universities.

All opinions expressed in this report are the author's and do not necessarily reflect the policies and views of the U.S. Nuclear Regulatory Commission, the U.S. Department of Energy, or the Oak Ridge Institute for Science and Education or any of their employees. Nor does it necessarily reflect the policies and views of the sponsoring institutions of Oak Ridge Associated Universities. 